\title{
LOYALTY IN CONSUMER BEHAVIOR: SOCIOLOGICAL DETERMINANTS
}

УДК 303.4:316.334.2

DOI https://doi.org/10.32843/2663-

5208.2020.17.2

\section{щерба О.І.}

к.соціол.н., доцент,

докторант відділу історії

та теорії соціології

Інститут соціології Національної

академії наук України
У статті розглянуто теоретичні основи дослідження лояльності споживачів до виробника/товару/послуги/торгівельної марки таких дослідників, як У. Уелс, Дж. Бернет, С. Mopiapmi, Дж. Росcimep, Л. Персі, А. Д. Аакер, Р. Олівер, Дж. Кул, Дж. Бекмен, Дж. Пенк, Т. Будзинський, М. Шнайдер, А. Веліцька, В. Урбан, Д. Семеняко, Б. Ольшевська, К. Мазурек-Лопацінська, Ф. Котлер, К. Келлер, Г. Ассель, А. Матанцев, М. Лучак, Д. Іган, і зроблено висновок, що не завжди активне споживання певних товарів означає лояльність з боку споживачів, як і не завжди значна лояльність у споживачів приводить до прибутковості підприємства. Показано, що виявлення й оцінювання соціально-психологічних механізмів лояльності дають виробникам змогу аналізувати взаємовідносини зі своїми споживачами та корегувати їх. Проаналізовано чотири послідовні етапи формування споживчої лояльності: (1) когнітивну, (2) афеективну, (3) поведінкову лояльність і (4) лояльність дії. Наголошено на тому, що ефеективні відносини між компанією та споживачем повинні створювати додану вартість для обох сторін. Подано нові характеристики, притаманні сучасним споживачам, що утворилися в результаті змін умов життя. Розглянуто відмінності в поведінці споживачів залежно від рівня ангажованості. Описано співпрацю виробника товару/послуги зі споживачем на трьох етапах: (1) проектування товару, (2) його втілення та (3) підтримка відносин після трансакції. Наголошено на важливості для виробників розробляти програмне забезпечення для управління взаємовідносинами зі споживачами (CRM). Виокремлено чотири групи споживачів: (1) дорогоцінні споживачі, (2) споживачі з високим потенціалом, (3) віддані неприбуткові споживачі, (4) споживачі, котрі не приносять прибутку, а також маркетингові стратегії їх взаємовідносин із виробниками.

Ключові слова: лояльність споживачів, ангажованість споживачів, формування лояльності, співпрачя зі споживачем, соціальна установка.

The article reviews the theoretical basis of the study of consumer loyalty to the enterprise/ product/service/brand of such researchers as W. Wells, J. Burnett, S. Moriarty, J. Rossiter, L. Percy, A. Aaker, R. Oliver, J. Kuhl, J. Beckmann, J. Penc, T. Budzinski, M. Snajder, A. Welicka, W. Urban, D. Siemieniako, B. Olszewska, K. Mazurek-Lopacinska, F. Kotler, K. Keller, G. Assel, A. Matancev, M. Luczak, D. Egan. It is concluded that not always active consumption of certain goods means loyalty of consumers, as well as not always significant loyalty of consumers leads to the profitability of the enterprise. It is shown that the identification and evaluation of socio-psychological mechanisms of loyalty allow manufacturers to analyze the relationship with their customers and adjust them. Four sequential stages of formation of consumer loyalty are analyzed: (1) cognitive, (2) affective, (3) behavioral loyalty and (4) action loyalty. It is emphasized that an effective relationship between the company and the consumer must create added value for both parties. The new characteristics of modern consumers, formed as a result of changes in modern living conditions, are presented. Differences in consumer behavior depending on the level of engagement are considered. The cooperation of the producer of the product/service with the consumer is described in three stages: (1) design of the product, (2) its implementation and (3) maintenance of relations after the transaction. The importance for businesses to develop customer relationship management (CRM) software is emphasized. Four groups of consumers as well as corresponding marketing strategies for their relationships with manufacturing enterprises were differentiated: (1) precious consumers, (2) consumers with high potential, (3) loyal non-profit consumers, (4) nonprofit consumers.

Key words: consumer loyalty, consumer engagement, loyalty formation, cooperation with the consumer, social attitude.
Постановка проблеми. Сучасні ринкові відносини, у тому числі й в Україні, характеризуються значним зростанням ролі споживача. Наявні ще донедавна труднощі, пов'язані з доступом до інформації або вдалої пропозиції, зникли в результаті стрімкого розвитку логістики та комунікаційної сфери. Важливим став також розвиток фінансових інструментів, включаючи онлайн-платежі, міжнародні перекази й обслуговування систем кредитування. Значення, що постійно зростає, електронної комерції відкрило доступ до нових товарів і послуг. Зріс не лише товарний ринок, а й кількість потенційних споживачів. Це означає, що виробники отримали легший доступ до більшої кількості потенційних споживачів, а спо- живачі отримали доступ до більшої кількості товарів і послуг i, найголовніше, можливості вибору.

Така ринкова кон'юнктура означає, що вагомого значення набувають програми, метою яких є втримування наявних споживачів і залучення нових. Особливо важливим стає підтримування контакту зі споживачем для отримання безпосередньої інформації та співпраці у створенні ринкової пропозиції. Це пояснює актуальність обраної для дослідження теми.

Аналіз останніх досліджень і публікацій. Питання, пов'язані з формуванням лояльності в індивідуального споживача, були об'єктом вивчення таких учених, як У. Уелс, Дж. Бернет, С. Моріарті, Дж. Россітер, Л. Персі, А.Д. Аакер, 
Р. Олівер, Дж. Кул, Дж. Бекмен, Дж. Пенк, Т. Будзинський, М. Шнайдер, А. Веліцька, В. Урбан, Д. Семеняко, Б. Ольшевська, К. Мазурек-Лопацінська, Ф. Котлер, К. Келлер, Г. Ассель, А. Матанцев, М. Лучак, Д. Іган та ін.

Постановка завдання. Метою статті $€$ визначення основних підходів у формуванні лояльності споживачів та окреслення площин прийняття рішень у процесі формування відносин виробника зі споживачем.

Виклад основного матеріалу дослідження. Феномен лояльності є одним із актуальних напрямів вивчення поведінки споживачів - дисципліни, що утворилася на стику соціології, психології, економіки та маркетингу. Розглянемо цей феномен комплексно.

1. Поняття лояльності споживачів у суспільних науках

Учені У. Уелс, Дж. Бернет та С. Моріарті визначають лояльність у ставленні до торгової марки як стан, «коли товар привабливий споживачам у мірі, достатній для здійснення повторної покупки» [7]. Однак це визначення $€$ надто загальним, хоча передбачає раціональний складник лояльності.

Дослідники Дж. Россітер та Л. Персі в результаті численних прикладних досліджень визначили лояльність як «регулярне (повторюване) придбання товару певної марки, засноване на тривалому з нею знайомстві й позитивному до неї ставленні» [6]. Таке визначення вже містить поведінковий та емоційний компоненти лояльності, хоча є ще неповним.

Учений А.Д. Аакер першим увів конкретні емпіричні індикатори з виявлення рівня лояльності, визначивши його як «міру прихильності споживача до товару» [1]. На його думку, лояльність показує, який рівень імовірності переключення споживача на інший товар. При цьому з підвищенням рівня лояльності знижується схильність споживачів до сприйняття дій конкурентів. Це визначення містить раціональний компонент лояльності.

Як бачимо, ці автори визначають лояльність за допомогою таких ознак, які співвідносяться з емоційним, раціональним і поведінковим складниками лояльності. Усі три згадані складники лояльності практично повністю відповідають структурі установки, що містить когнітивний (переконання), афективний (почуття) і конативний (дія) аспекти.

Однією з найвагоміших сучасних пояснювальних моделей лояльності $€$ теорія, запропонована Р. Олівером, у якій учений, власне, і розглядає лояльність як особливий вид установки. Цей дослідник визначає лояльність як глибоко збережене зобов'язання купувати товар або послугу, якому він надає перевагу, залишаючись його споживачем у майбутньому, яке призводить до повторних покупок однієї й тієї самої марки, незважаючи на вплив ситуації й можливість вибрати товар або послугу іншої марки [12]. При цьому, орієнтуючись на основні змістові компоненти атитюду, Р. Олівер виділяє чотири послідовні етапи формування споживчої лояльності: (1) когнітивну; (2) афективну; (3) поведінкову лояльність і (4) лояльність дії.

(1) Когнітивна лояльність - перша стадія розвитку споживчої лояльності. Згідно з Р. Олівером, вона передбачає наявність інформації про атрибути торгівельної марки, яка дає споживачеві змогу оцінити його як кращий, ніж інші альтернативи. На цій стадії лояльність заснована виключно на уявленнях про марку, джерелами яких $є$ як знання, отримані раніше в результаті прямого або вікарного навчання, так і власний недавній досвід. Об'єктом лояльності тут $€$ сама марка. Рівень лояльності на цій стадії залежить від характеру роботи сприйняття й усвідомлення обробки інформації. Якщо взаємодія індивіда з об'єктом відбувається на рівні поведінкових автоматизмів і його досвід завжди рутинний, інформація про марку буде швидше поверховою. Наприклад, ми можемо нічого не знати про торгівельну марку письмового стола, за яким працюємо щодня. Якщо ж індивід постійно і свідомо переживає досвід взаємодії з товаром, то він не тільки отримує більше інформації про нього, а й запам'ятовує емоційне забарвлення цього досвіду.

(2) Друга стадія розвитку лояльності афективна лояльність, що характеризується появою емоційної прихильності до торгівельної марки на основі неодноразового позитивно забарвленого досвіду взаємодії з ним. Як наслідок позитивного досвіду споживання на цій стадії одним із факторів лояльності стає відчуття задоволення. Роль афекту в загальній лояльній установці дуже важлива. Будь-які судження про торгівельну марку можуть бути поставлені під сумнів і піддані контраргументації, але відкинути пережиті емоції набагато складніше. Отже, рівень прихильності споживача визначається глибиною пережитих ним емоцій у процесі взаємодії з маркою.

(3) На основі емоційної прихильності може виникнути поведінкова лояльність, об'єктом якої стає не марка, а споживання конкретної марки. Ця установка передбачає наявність мотивації до споживання й повторних покупок марки, яка може й не усвідомлюватися індивідом до певного часу.

(4) Остання стадія розвитку споживчої лояльності, за Р. Олівером, - це лояльність дії. Під час опису її механізмів він опирається на мотиваційну теорію контролю за дією [9], відповідно до якої мотив до дії, сформований на попередній стадії, трансформується в готовність до дії. Цей перехід супроводжується додатковою установкою на подолання 
перешкод, що заважають дії. Сама дія розуміється як результат обов'язкового включення обох інтенцій (до покупки й до подолання перешкод, що виникають). Якщо це поєднання повторюється кілька разів, то далі споживання перетворюється в поведінковий автоматизм, звичку, яка призводить до регулярного повторного споживання. Виокремлення стадії лояльності дії є специфічною відмінністю атитюдної моделі Р. Олівера від запропонованих іншими дослідниками раніше. У цій моделі установка на торгівельну марку трансформується в установку на його споживання, яка закріплюється й автоматизується в дії.

Отже, визначення лояльності, що прийшли з економіки та маркетингу, не суперечать тому, що лояльність $є$ соціально-психологічною категорією. Як ми бачимо, у психології поняття лояльності й установки повністю ототожнюються. Однак у соціології ці поняття ми розмежовуємо, оскільки вважаємо поняття лояльності ширшим за соціальну установку.

Ефективні відносини між компанією та споживачем повинні створювати додану вартість для обох сторін. Це означає, що процес створення відносин повинен ураховувати цілі, установлені обома сторонами. Варто також ураховувати поведінку та готовність окремих споживачів до співпраці з виробниками. Отже, побудова взаємовідносин повинна базуватися на визнанні індивідуальних характеристик споживача та співвідношенні їх із потребами й можливостями виробника. Цей аналіз може проводитися в площині способу пошуку інформації, проектування сфери співпраці та рівня ангажованості сторін. Розглянемо, як відбувається процес формування лояльності в споживачів детальніше.

2. Процес формування лояльності в споживачів

У наш час споживачі мають усе більший вибір місця, часу й умов для здійснення покупок, починаючи від ринків, мікро-, малих, середніх і великих магазинів, супермаркетів, гіпермаркетів, дисконтних магазинів, спеціалізованих магазинів і закінчуючи торговими центрами.

Збільшення обізнаності, легкий доступ до інформації, усвідомлення можливості вибору між різними групами товарів і ринкових послуг мають фундаментальний вплив на поведінку споживачів. Тому виробник повинен бути готовим представити пропозицію, яка є вигіднішою за інші за ціною, якістю чи характеристиками, що впливають на рішення про укладення угоди. У побутовій формі - це суперництво або змагання двох (чи більше) більш-менш рівних суперників [14, с. 199].

За даними аналітиків ринку, 70\% рішень про купівлю покупці приймають усередині магазину [8, с. 105]. Тому виробники намагаються виокремитися серед конкурентів не лише низькими цінами, привабливою пропозицією, а й дизайном інтер'єру, відповідною викладкою товарів на полицях, атмосферою та якістю обслуговування, професійними порадами.

Здійснюючи вибір покупки, споживачі піддаються ситуаційним стимулам, які значною мірою залежать від контексту прийняття рішень і середовища, у якому вони роблять свій вибір. Висока тенденція до імпульсної поведінки не $€$ загальною характеристикою в населення. Тим не менше в кожної людини можна спостерігати поведінку з характеристиками імпульсних рефлексів [15, с. 100].

Лояльність споживачів може стосуватися одного або різних об'єктів, пов'язаних із виробником: торгівельна марка, категорія товару, персонал компанії, місце придбання, набір об'єктів у межах спільноти навколо торгівельної марки, організації [16, с. 20]. «Сучасний споживач усе частіше вимагає до себе індивідуального підходу, не хоче бути анонімним, хоче бути ідентифікованим, хоче брати участь у формуванні виробів» [13, с. 47]. Поступові зміни умов життя й мегатренди в навколишньому середовищі сприяють виробленню нових характеристик, притаманних сучасним споживачам:

а) споживач більше усвідомлює свої права й має раціональніше ставлення до комерційної пропозиції;

б) потреба в соціальних зв'язках призводить до використання саме тих товарів і послуг, які пов'язують групи людей;

в) споживачі мають більше стратегічних навичок управління своїм бюджетом, ніж раніше;

г) споживач стає «полікультурним», з одного боку, у нього простежується тенденція піддаватися впливу глобальним бізнес-стратегіям виробників, а з іншого - він прагне підтримувати свою ідентичність і культурну специфіку;

д) споживачі стають мобільнішими, інтегруються в різні види діяльності з іншими, а також прагнуть захистити природне середовище, споживають екологічну продукцію та використовують упаковку, яка біологічно розкладається [11, с. 28-29].

Одним із факторів, що впливає на досягнення споживчої лояльності, $€$ ангажованість споживачів. Згідно з Ф. Котлером, під ангажованістю споживача варто розуміти рівень його зацікавленості в торгівельній марці (фірмі) й обсяг обробки інформації, що виникає в результаті реакції на маркетинговий подразник [4]. Ангажованість у загальному вигляді показує рівень зацікавленості та емоційного переживання в процесі вибору товару.

Відмінності в поведінці споживачів залежно від рівня ангажованості сформулював Г. Ассель 
[2]. Так, модель поведінки при високій ангажованості характеризується поглибленим процесом обробки інформації, усвідомленим пошуком інформації, тісним взаємозв'язком товару з особистістю і стилем життя споживача. У разі ж низької ангажованості споживач випадково сприймає інформацію, а здійснювані покупки не $€$ значущими з погляду норм і цінностей його референтної групи. Виходячи із цього, особливе значення сприймана соціальна відповідальність компанії матиме для споживачів із високим рівнем залученості й соціально-відповідальною поведінкою (соціально відповідальна поведінка споживачів може виражатися, наприклад, у споживанні тих продуктів, які безпечні для навколишнього середовища, або готовності платити більше за такі товари).

Хоча задоволеність і втримування споживачів $\epsilon$ важливими показниками ефективності маркетингу, для лояльності споживачів необхідний інший рівень психологічної прихильності. Існує багато способів оцінювання психологічної прихильності споживача до певної марки або виробника, але серед усіх інших найвищою формою емоційного схвалення $є$ рекомендація, що загалом $є$ відповіддю на питання «Яка ймовірність того, що ви порекомендуєте цю марку або виробника іншим покупцям?» Коли споживачі позитивно відгукуються про якийсь товар або послугу, це означає, що в них $€$ тверда впевненість у цінності товару або послуги, що пропонуються виробником або торгівельною маркою як рекомендовані [5].

Рівень залучення споживачів може змінюватися залежно від соціальної відповідальності виробника. Покупці схильні купувати товари у виробників, які залучені в соціально-значущі проекти.

Форма й характер відносин зі споживачем також залежить від прийнятої сфери співпраці, що проаналізуємо детальніше.

\section{3. Сфера співпраці зі споживачем}

Аналіз важливості описуваних відносин зі споживачами в процесі формування конкурентних переваг свідчить про велике значення спільного створення доданої вартості на трьох етапах: (1) проектування товару, (2) його втілення та (3) підтримка відносин після трансакції [10].

(1) Розроблення пропозиції - це етап, на якому споживач може брати активну участь у розробленні нових товарів. Зрештою, прямий обмін інформацією є цінним ресурсом для виробників. Запрошення майбутніх споживачів до оцінювання проектів, а потім збирання їхніх коментарів і пропозицій стає основою для підготовки пропозиції, більш пристосованої до вимог покупців. Більше того, участь споживача в проектуванні товару перетворюється на його участь у цілому виробничому процесі. Цей етап набуває характеру особистої участі майбутніх покупців у формі нової ринкової пропо- зиції, що готується. Ключовим елементом тут є забезпечення швидкого та прямого спілкування. Корисним у цьому стосунку є допомога Інтернету, особливо соціальних мереж, що об'єднують потенційних споживачів. Вони дають змогу обмінюватися досвідом і думками між покупцями та виробником.

(2) Завершення пропозиції $€$ важливим фактором у процесі прийняття рішення про придбання. Можливість адаптувати пропозицію все частіше стає ключовим стимулом, що впливає на поведінку покупців. Через зменшення ролі географічного чинника сегменти в основному виокремлюють на основі потреб споживачів, які часто територіально віддалені. Використання Інтернету для представлення детальної пропозиції уможливило обирання конкретного товару практично всіма користувачами Інтернету у світі, а доставка товарів залежить від можливостей фірм із доставки товарів. Тому компанія може зосередитися на підготовці варіантів пропозиції або навіть надати перелік компонентів, із яких споживач може скласти індивідуальну пропозицію. Тут стають необхідними сучасні рішення електронної комерції у вигляді розширених додатків Інтернет-магазинів, які часто використовують також і для втримування покупців за допомогою спеціального стимулювання. Програмне забезпечення для управління цими взаємовідносинами називається управлінням взаємовідносинами зі споживачами (CRM).

Управління взаємовідносинами зі споживачами (CRM) - це процес управління всіма елементами взаємин, які існують між фірмою та її реальними або потенційними споживачами. Останніми роками багато виробників розробили програмне забезпечення для підтримки цього процесу.

(3) Насамкінець дуже важливо підтримувати контакт між виробником і покупцем після трансакції. Метою підтримання післяпродажного контакту $є$ сприяння лояльності споживачів. Ефектом співпраці на цьому етапі $€$ обмін інформацією про використання товару або задоволення послугою. Також надається інформація про бажані споживачами зміни, що стимулюють інноваційний процес на підприємстві. Найефективнішими інструментами для підтримки контактів тут є соціальні мережі та Інтернет-портали, що об'єднують наявних і майбутніх споживачів.

Задоволеність і втримування споживачів позитивно впливають на рентабельність, однак у виробника можуть бути такі споживачі, яких хочеться втримати, і такі, від яких хотілося б відмовитися. Для ефективного управління взаємовідносинами зі споживачами з погляду їх втримування доречно провести їх класифікацію за показниками лояльності і прибутковості. Не всі споживачі однакові. Одні можуть 
бути лояльними і прибутковими, інші прибутковими, але нелояльними, деякі лояльними, але неприбутковими, а решта - ні прибутковими, ні лояльними. Одна із цілей стратегії взаємовідносин зі споживачами полягає в урегулюванні цих відмінностей з метою досягнення високого рівня і прибутковості.

Розглянемо й охарактеризуємо кожну групу покупців і стратегії взаємовідносин детальніше:

(1) Дорогоцінні споживачі: покупці, які характеризуються поєднанням лояльності і прибутковості, що перевищують середні значення показників. Основною стратегією взаємин із ними буде інвестування в спеціальні програми розвитку стійких, довгострокових відносин з індивідуальним підходом, що дають змогу досягти максимальної задоволеності.

(2) Споживачі 3 високим потенціалом: покупці, що володіють високим потенціалом створення прибутку, але слабкою лояльністю. Основною стратегією взаємин із цією групою має стати інвестування в програми формування відданості на основі спеціальних пропозицій, що підсилюють споживчу задоволеність і бажання залишитися з виробником.

(3) Віддані неприбуткові покупці: украй лояльні споживачі, що володіють невисоким потенціалом створення прибутку. Відповідною стратегією взаємин із такими покупцями буде інвестування в спеціальні програми, які надають їм більше можливостей для покупок у новому форматі на пільгових умовах.

(4) Споживачі, які не приносять прибутку: не зовсім вигідні для виробника покупці-початківці, покупці-перебіжчики, покупці, які роблять покупку один раз. Основна стратегія взаємин із такими різними покупцями має бути пов'язана з розмежуванням потенційно прибуткових новачків від тих, котрі не приносять прибутку за рахунок забезпечення вищого рівня сервісу й задоволеності. Також важливим $€$ не допустити безконтрольність формування бази споживачів, які ні лояльні, ні прибуткові [3].

Вибір правильного набору інструментів для управління відносинами зі споживачем на різних етапах співпраці може стати запорукою успіху маркетингової стратегії виробника, а правильне використання доступних Інтернет-інструментів - забезпечити швидкий і прямий доступ до широкого кола покупців. Тому завданням виробника $є$ підготовка правильного плану впровадження окремих інструментів.

Висновки з проведеного дослідження. Отже, проаналізувавши доробок учених щодо поняття лояльності, ми побачили, що не завжди активне споживання певних товарів означає лояльність з боку споживачів, як і не завжди значна лояльність у споживачів приводить до прибутковості виробника. Однак саме виявлення й оцінювання соціально-психологічних механізмів лояльності дадуть виробникам змогу аналізувати взаємовідносини зі своїми споживачами та корегувати їх. В умовах економічної кризи 2020 року, на нашу думку, саме індивідуалізація споживання дасть виробникам можливість зберегти своє коло споживачів, отримуючи при цьому прибутки.

\section{ЛІТЕРАТУРА:}

1. Аакер Д.А. Создание сильных брендов. Москва : Издательский дом Гребенникова, 2008. $440 \mathrm{c}$.

2. Ассэль Г. Маркетинг: принципы и стратегия. Москва : Инфрра-М : НФПК NTF, 2001. 803 с.

3. Иган Д. Маркетинг взаимоотношений: анализ маркетинговых стратегий на основе взаимоотношений. Москва : Юнити, 2015. 375 с.

4. Котлер Ф., Келлер К.Л. Маркетинг-менеджмент. Санкт-Петербург : Питер, 2007. 814 с.

5. Матанцев А.Н. Искусство завоевать рынок. Москва : Экономист, 2006. 512 с.

6. Росситер Дж.Р., Перси Л. Реклама и продвижение товаров. Санкт-Петербург : Питер, 2001. 656 с.

7. Уэллс У., Бернет Дж., Мориарти С. Реклама: принципы и практика. Санкт-Петербург : Питер, 2001. 797 c.

8. Budziński T. Specjaliści od produktów impulsowych. Poradnik Handlowca. 2008. № 4. S. 100-112.

9. Kuhl J., Beckmann J. Historical Perspectives in the Study of Action Control. Action Control: From Cognition to Behavior, Julius Kuhl and Jurgen Beckmann, eds. Berlin : Springer-Verlag, 1985. P. 89-100.

10. Łuczak M. Wzrost znaczenia relacji z konsumentem jakokierunek rozwoju koncepcji marketingu międzynarodowego. Marketing międzynarodowy. Uwarunkowania i kierunki rozwoju / pod red. J.W. Wiktor, A. Żbikowska. Warszawa : PWE, 2010. S. 266-272.

11. Mazurek-Łopacińska K. Zachowania nabywców i ich konsekwencje marketingowe. Warszawa : PWE, 2003. $368 \mathrm{~s}$.

12. Oliver R.L. Whence consumer loyalty? Journal of Marketing. 1999. Vol. 63. P. 33-44.

13. Olszewska B. Prymat klienta. W: Zarządzanie strategiczne. Przedsiębiorstwo na progu XXI wieku I pod red. B. Olszewska. Wrocław : Wyd. Uniwersytetu Ekonomicznego we Wrocławiu, 2008. $245 \mathrm{~s}$.

14. Penc J. Leksykon biznesu. Warszawa : Agencja Wydawnicza Placet, 1997. $591 \mathrm{~s}$.

15. Sznajder M., Wielicka A., Impulsowość w zachowaniach zakupowych i konsumpcyjnych. Mruk H., Sznajder M. Neuromarketing. Interdyscyplinarne spojrzenie na klienta. Poznań : Wyd. Un-tu Przyrodniczego w Poznaniu, 2008.

16. Urban W., Siemieniako D. Lojalność klientów. Modele, motywacja i pomiar. Warszawa: Wyd. Naukowe PWN, 2008. 150 s. 